\title{
Entrepreneurship in the public university management of nursing: obstacles and strategies
}

\author{
Empreendedorismo na gestão universitária pública de enfermagem: entraves e estratégias
}

Fernanda Hannah da Silva Copelli ${ }^{1}$, Alacoque Lorenzini Erdmann ${ }^{1}$, José Luís Guedes dos Santos ${ }^{1}$, Gabriela Marcellino de Melo Lanzoni ${ }^{1}$, Selma Regina de Andrade ${ }^{1}$

Objective: to understand the obstacles to entrepreneurship in the public university management of nursing and the strategies to overcome them. Methods: it is a qualitative research with the theoretical-methodological contribution of Grounded Theory. Intensive interviews were conducted with 27 participants divided into three sample groups. Results: the obstacles to entrepreneurship in the university public nursing management are the bureaucratic management model, the lack of resources and infrastructure, the multiplicity of teaching activities, the lack of knowledge in entrepreneurship and university management and the difficulty in managing people. The strategies are the dissemination of entrepreneurship, the search for theoretical knowledge and the incentive to entrepreneurship in the academic community. Conclusion: the obstacles to entrepreneurship in the university public nursing management are organizational and personal and the strategies are education and dissemination of entrepreneurship.

Descriptors: Entrepreneurship; Nursing Administration Research; Education, Nursing.

Objetivo: compreender os entraves para o empreendedorismo na gestão universitária pública de enfermagem e as estratégias para superá-los. Métodos: pesquisa qualitativa com aporte teórico-metodológico da Teoria Fundamentada nos Dados. Foram realizadas entrevistas intensivas com 27 participantes divididos em três grupos amostrais. Resultados: os entraves para o empreendedorismo na gestão universitária pública de enfermagem são o modelo burocrático de gestão, a carência de recursos e infraestrutura, a multiplicidade de atividades docentes, a deficiência de conhecimento em empreendedorismo e gestão universitária e a dificuldade no gerenciamento de pessoas. As estratégias são a divulgação do empreendedorismo, a busca por conhecimento teórico e o incentivo ao empreendedorismo na comunidade acadêmica. Conclusão: os entraves ao empreendedorismo na gestão universitária pública de enfermagem são organizacionais e pessoais e as estratégias são educação e divulgação do empreendedorismo.

Descritores: Contrato de Risco; Pesquisa em Administração de Enfermagem; Educação em Enfermagem.

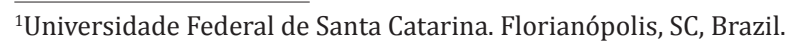

Corresponding author: Fernanda Hannah da Silva Copelli

Universidade Federal de Santa Catarina. Campus Universitário, Trindade, s/no. CEP: 88040-900. Florianópolis, SC, Brazil. E-mail: fernandacopelli@hotmail.com 


\section{Introduction}

Entrepreneurship is usually associated with the business sector and the entrepreneur is seen as the person who opens a company with the purpose of generating employment and income ${ }^{(1)}$. Still, in the $20^{\text {th }}$ century, the term appears in literature as an essential strategy for the economic development of Brazil, as well as promoting better living conditions for the society $^{(2)}$.

However, in spite of the entrepreneurial influence in entrepreneurship, it is necessary, in the contemporaneity, to broaden the view on the concept ${ }^{(1)}$, even to cover other areas of knowledge also appropriating this theme ${ }^{(3)}$. In this context, Nursing as science, technology, and profession has advanced in the incorporation of entrepreneurship in its practice. Some examples are the new fields of professional activity, such as the autonomous practice of counseling and consulting, the training of offices, home care, pre-hospital services and the construction of patents. Despite the advances and entrepreneurial practices already achieved, new possibilities still can and should be developed ${ }^{(4)}$. When enterprising, the nurse dares, explores opportunities and visualizes new spaces, making them protagonists from their professional practice $^{(5)}$.

For this, the education process occupies important space in the instrumentalization of new entrepreneurs $^{(3-4)}$. Graduate subjects focused on teaching nursing management, for example, expanding the development of managerial skills and knowledge, including the training of entrepreneurs ${ }^{(6)}$.

Thus, education is essential for the training of thinkers and leaders with an entrepreneurial profile in nursing ${ }^{(4,7)}$. However, there is a need to reformulate pedagogical proposals and existing university management services to modify parts of the curriculum and provide support, protection, and conditions for entrepreneurship education. The renewal of public universities for the incorporation of management that encompasses education and entrepreneurial culture is not easy but must be carried out to be in accordance with the most contemporary pedagogical proposals ${ }^{(8)}$.

Understanding the relevance of the influence that the university management has on the training and instrumentalization of an entrepreneurial profile for nursing and the need to consolidate an entrepreneurial culture in the profession, especially in the public and university context, the following guiding questions were elaborated: Are the obstacles to entrepreneurship in the public university nursing management? What strategies can be developed to overcome these obstacles?

To answer the aforementioned questions, this study aimed to understand the obstacles to entrepreneurship in the public university nursing management and the strategies to overcome them.

\section{Methods}

This is a qualitative research with the theoretical-methodological contribution of Grounded Theory ${ }^{(9)}$. It was performed at the Nursing Department of a public university in the South of Brazil. For the theoretical sampling, four sample groups were composed, making a total of 27 participants (P1-P27).

The first sample group (P1-P9) was intentionally delimited and constituted by nine university managers filled out in the Nursing Department. Teaching nurses who held university management positions were included, for example, head of the department, coordinator of undergraduate course and coordinators of research, extension, internship, nursing laboratory. The criterion of inclusion was a minimum of three months of experience in the university management position, based on that this is a minimum period of time for the manager to appropriate his activities. There were no exclusion criteria adopted.

The other sample groups came from the data analysis of the first sample group. In an auxiliary way, the network or "snowball" sampling strategy ${ }^{\left({ }^{(9)}\right.}$ was used.

The second sample group (P10-P15) was defi- 
ned by six university nurses, former university managers, especially former heads of the Nursing Department. The third sample group (P16-P21) consisted of six teaching nurses from the Nursing Department. Six nursing students participated in the fourth sample group (P22-P27) - three undergraduate nursing students and three post-graduate students of the postgraduate nursing program of the aforementioned public university.

The hypotheses that guided the formation of the second, third and fourth sample group arose from the analysis of the first group. According to these participants, the former managers would be the most indicated to evaluate the university management as a whole and the teachers and students would be the people most influenced by the entrepreneurship in the university context. The theoretical sample size was determined by the theoretical saturation of the data ${ }^{(9)}$.

The data collection was done through intensive interviews $^{(9)}$ that focused on the obstacles encountered by the teaching nurses for entrepreneurship in university management, as well as the strategies to overcome them. They were done individually in the workplace or in an environment chosen by the participants, from January to July 2015, with an average duration of 30 minutes, recorded in a digital medium and transcribed in full. Participants' statements were identified by codes composed of the letter "P" of the participant, followed by the ordinal number of each interview (for example P1, P2, ..., P27).

The data collection and analysis occurred simultaneously through the initial and focused coding ${ }^{(9)}$. In the initial coding, the incidents obtained from the transcripts generated provisional, comparative and data-based codes. In the focused coding, the most significant and/or frequent codes were grouped by similarities and conceptual differences, forming categories with more abstract names that synthesized and explained a larger segment of data (incident/incident) ${ }^{(9)}$.

From the process of analysis, the phenomenon
(Intra) enterprising was built collectively in the public university management of nursing. Two categories were focused due to the representativeness for the emergence of the phenomenon: Obstacles for entrepreneurship in the university public management of nursing and Strategies for expanding entrepreneurship in the public university nursing management.

The study complied with the formal requirements contained in the national and international regulatory standards for research involving human beings.

\section{Results}

The category Obstacles for entrepreneurship in the public university nursing management was constituted by five subcategories, and the category Strategies for expanding entrepreneurship in the public university management of nursing was constituted by three subcategories. In the sequence, each one is presented.

\section{Obstacles to entrepreneurship in public university nursing management}

This category shows the difficulties of the bureaucratic model of the university management, the lack of resources and infrastructure to increase and optimize the multiplicity of teaching activities and managers, especially in people management, since knowledge in entrepreneurship and university management is still in its beginning.

In the first subcategory, Difficulties of the bureaucratic model of university management, the bureaucracy of the public system was listed as the main difficulty for entrepreneurship in university nursing management, as the speeches show: I think the biggest disadvantage is the extreme bureaucracy, harming too much the work (P7). ... The university management continues in the same way, the same bureaucracy that does not allow us to go much further (P10). I think that bureaucracy is one of the most important barriers because 
often within the department the ideas come, the projects are built, but the question of deadlines, passing time and passing in a meeting ends up causing some possibilities to be lost (P21).

The second subcategory, Lack of Resources and Infrastructure points out that lack of resources and infrastructure also hinders entrepreneurship in the university management due, for example, to a decrease in financial resources, a lack of support staff, difficulty with the availability of material and infrastructure, as presented in the statements: The issue of infrastructure and budget. We do not have a support structure in here (P2). Today we could have a scholarship holder, but they [department] do not realize that there is no one who can help (P6). Sometimes we have some difficulty with the material, sometimes delay (P9).

In the third subcategory, Multiplicity of teaching activities, the managers, and teachers participating in the study highlighted the various tasks they carry out in daily work. Managers, in particular, referred to a complication in reconciling teaching, research and extension activities when they assume managerial positions: A barrier that is always very important for us is the barrier of our own workload that is insufficient for the demand (P4). So for us to take care of being a manager, to continue producing, to continue writing, to continue the academic career, you suffer a lot, it's a very big wear and tears, these are the big disadvantages (P7). I think we have many functions for how little time we have. This generates overload, people get sick and stress. This I think brings down the productivity of knowledge a little (P18).

The fourth subcategory, Knowledge Disability in Entrepreneurship and University Management, underscores the low level of dissemination of these themes in the academic world and the lack of formal qualification in both areas, as the speeches show: We would need to have courses or skills to improve, have a better management knowledge to be able to perform this position better. I think there are two barriers or difficulties, the training issue, which I think we would need more, we never really had (P5). I think the biggest barrier is not talking about entrepreneurship. It is a very incipient subject (P24). I believe that the lack of knowledge and experience are barriers (P17).

In the fifth category, Difficulties in managing people, there was another aspect that undermines the development of entrepreneurship in the public uni- versity management of nursing, which stems from the inherent difficulty of management practice, in tangent to the management of people. ... It's always a very challenging thing for you to do people management (P11).... You deal with people at different times in your life, there is one who wants to invest in the career, there is another who is already in a moment that is not investing. I think this is the hardest (P12).... You live with highly qualified, perhaps not so politicized, but highly qualified people (P13).

\section{Strategies for expanding entrepreneurship in public university nursing management}

In the second category, the dissemination of the theme, the need for theoretical deepening and the incentive to entrepreneurship in nursing in the academic community are highlighted as strategies.

The first subcategory, Dissemination of the theme of entrepreneurship, points out that the communication of the theme through research groups, collective discussions, and conversational rounds expands the entrepreneurship in the university context, according to the statements: We would have to make groups, discussions... (P18). Communication, to have a group, to have someone to spread it, to talk ... I think I needed to have a wider dissemination, discussion thread, discussion about the theme (P24). I think entrepreneurship is being done in some way, from meetings between students and coordination. This is a strategy to increase entrepreneurship (P26).

The second subcategory, Search for theoretical knowledge on entrepreneurship and university management, states that the search for knowledge through training can contribute to the expansion of entrepreneurship in university nursing management, as the speeches show: Knowledge for me is linked to entrepreneurship, you cannot advance, make new proposals, ways of acting without knowledge (P5). ... Training is necessary, I do not think anyone can say that everyone is prepared, it is not! They must have a preparation for management, they must have a specific training for university management (P11).... All the positions that I have exercised I have always studied on management, not only on university management but on management in general, I have always tried to keep myself updated (P12). 
In the third category, Incentive to entrepreneurship in nursing in the academic community, the participants mentioned that having an entrepreneurial profile, behavior or attitude can be an inspiration for other managers, teachers and nursing students, increasing entrepreneurship in university management as a whole, as the statements show: A very motivating thing is when you realize that you are involving people ... you work with the skills of people, people automatically come to give you ideas, come to offer you help, come and tell you things (P1). It's not just about being enterprising, but about being enterprising about what you do. In this sense, I have a duty to encourage students to be future entrepreneurs (P9). I am a guy who has an entrepreneurial behavior ... if a manager is not an entrepreneur, does not resolve to face problems and challenges all the time in a different way, he will pass without being remembered (P13).

\section{Discussion}

The limitations are related to the difficulty of generalizing the results and their applicability in different contexts, although the study details information that respects the perspectives of the participants for the recognition of a phenomenon still little explored in the nursing area.

The bureaucratic model of university management was evidenced as a barrier to entrepreneurship by hindering the progress of teaching work, especially in the development of new ideas and academic projects. In Brazil, bureaucracy is an inherent characteristic of the public sector ${ }^{(10)}$ and, in this sense, it is up to managers to develop strategies to minimize these effects.

Also regarding the organizational context of the university, insufficient resources and infrastructure are difficulties for entrepreneurship, mainly due to lack of funding, physical structure, material and support staff. This lack is recurrent in the public system. However, it is not a reason not to be enterprising, which consists precisely in having the creativity to overcome the barriers. Thus, the lack of resources can be partially covered by the search for financing through research and extension projects, as well as by calls for proposals in development agencies and partnerships with private companies ${ }^{(11)}$.

Regarding the multiplicity of teaching activities, the participants highlighted the issue of insufficient workload for the demand for managerial actions, hindering to maintain the quality of teaching, research, and extension. This generates overwork, wear, and impairment of teachers' health conditions. This study warns that the exercise of management positions is an inherent part of the process of being a teacher and contributes to the insertion and professional development in the university context ${ }^{(12)}$. However, university management in the Brazilian context is not always as valued as teaching, research and extension activities, and it is seen as an overload in the other activities most valued in the teaching work.

The health conditions of university teachers deserve attention when dealing with the discussion about the overload of the teaching service. A study on psychological demand and control over work has shown that university nurses professors somatize effects of the various activities they perform in teaching, research, and extension of undergraduate and postgraduate courses, generating greater psychological demand and repercussions on psychic health ${ }^{(13)}$.

Another finding of this study revealed the lack of knowledge in entrepreneurship and university management. Participants ensured this deficiency to incipience, lack of dissemination and lack of capacity building in the themes. Thus, investments in this knowledge area need to be done in nursing. Education in entrepreneurship must be considered for nurses to be prepared to act in different spaces, to become more creative, innovative and sustainable ${ }^{(4)}$.

Finally, it was evidenced the difficulty of managing people, which is a generalized barrier in any administrative function ${ }^{(14)}$. However, entrepreneurs must assume activities of people management, human and social development ${ }^{(15)}$. 
Based on the difficulties presented, the strategies to overcome them emerged. The results evidenced that the theme still needs to be communicated and disseminated in nursing from groups, talk circles, and discussions in general. The incipience of the concept in its multiple typologies is shown in another study that sought to analyze social and corporate responsibility in the perspective of entrepreneurship ${ }^{(16)}$. To do so, it is necessary to create environments conducive to the dissemination and teaching of entrepreneurship, in which space for discussion and reflection on the theme are included.

Another strategy mentioned was the search for theoretical knowledge, related to the personal need for updating and training. Thus, the academic and professional development of the teaching staff is fundamental both for their individual success and for the success and visibility of the institution they are linked $^{(17) .}$

The last strategy highlighted by the participants of this study was the incentive of entrepreneurship in nursing among the academic community, based on the example that the teacher with an entrepreneurial profile has and represents the other teachers, students, and university managers. The literature suggests that an entrepreneurial profile requires a series of knowledge, skills, and attitudes. Among them, the ability to relate and aggregate personnel infected by a culture or entrepreneurial spirit ${ }^{(18)}$ stands out, aiming at the achievement of common goals and objectives.

This study offers contributions to the area of university management in nursing in the possibility of presenting and understanding the obstacles to the entrepreneurship process, considering the multiplicity of teaching activities in the daily work. Also, it provides subsidies and strategies for the development of the culture of entrepreneurship among university managers, teachers, and nursing students, through dissemination in academic and cultural environments and the encouragement of different approaches related to the entrepreneurial essence.

\section{Conclusion}

The obstacles are organizational, related to the public context in which this study was applied, and personal, which arise from the participants' own difficulties due to lack of culture to management and entrepreneurship in nursing. Strategies are related to entrepreneurial education supported by the need to search for knowledge and to disseminate the theme.

\section{Collaborations}

Copelli FHS, Erdmann AL and Santos JLG contributed in the design and project, analysis and interpretation of data and article writing. Lanzoni GMM and Andrade SR contributed to the writing of the article. All authors contributed to the relevant critical review of intellectual content and final approval of the version to be published.

\section{References}

1. Silva FF, Lima HCR, Silva MFBF. Experiências exitosas no ensino universitário de empreendedorismo. Veredas Favip [Internet]. 2015 [citado 2016 ago. 03]; 8(2):36-50. Disponível em: http://veredas.favip.edu.br/ojs/index.php/ veredas1/article/view/266/327

2. Bernardo NRR, Tadeucci MSR, Araujo EAS. A importância da instituição pública de ensino superior tecnológico para o ensino do empreendedorismo: análise do curso superior de tecnologia em gestão empresarial, na cidade de Guaratinguetá. Janus [Internet]. 2013 [citado 2016 ago. 03]; 10(17):11-40. Disponível em: http://publicacoes.fatea.br/index.php/janus/ article/view/914/697

3. Barbosa FLS, Rabêlo Neto A, Moreira RN, Bizarria FPA. Empresa júnior e formação empreendedora de discentes do curso de administração. Rev TPA [Internet]. 2015 [citado 2016 ago. 03]; 5(2):16789. Disponível em: http://periodicos.ufpb.br/ index.php/tpa/article/view/25026/14436 
4. Erdmann AL, Backes DS, Alves A, Albino AT, Farias F, Guerini IC, et al. Formando empreendedores na enfermagem: Promovendo competências e aptidões sócio-políticas. Enferm Glob [Internet]. 2009 [citado 2016 ago. 03]; (16):1-10. Disponível em:http://scielo.isciii.es/pdf/eg/n16/pt_ administracion3.pdf

5. AndradeAC,Ben LWD,SannaMC.Entrepreneurship in Nursing: overview of companies in the State of São Paulo. Rev Bras Enferm. 2015; 68(1):404. doi: http://dx.doi.org/10.1590/00347167.2015680106p

6. Santos JLG, Pestana AL, Guerrero P, Klock P, Erdmann AL. Logbook: experience of teachinglearning management and management in nursing and health. Rev Rene [Internet]. 2013 [cited 2017 Jun 13]; 14(4):854-63. Available from: http://www.revistarene.ufc.br/revista/index. $\mathrm{php} / \mathrm{revista/article/view/1467}$

7. Tavares CEM, Moura GL, Alves JN. Educação empreendedora e a geração de novos negócios. Rev Acad Econom [Internet]. 2013 [citado 2017 set. 19]; 188:1-8. Disponível em: http://www.eumed. net/cursecon/ecolat/br/13/empreendedorismo. html

8. Campos LRG, Ribeiro MRR. Gestão do trabalho docente em uma faculdade de enfermagem - percepção de gestores. Rev Gestão Saúde [Internet]. 2013 [citado 2016 ago. 3]; 4(3):87185. Disponível em: http://periodicos.unb.br/ index.php/rgs/article/view/14157/10085

9. Charmaz K. A construção da teoria fundamentada: guia prático para análise qualitativa. Porto Alegre: Artmed; 2009.

10. Montenegro Junior CAA, Vieira MG. A busca pela eficiência no serviço público, através da lei de acesso à informação e as relações com o aprimoramento da gestão da informação. Saber Hum [Internet]. 2016 [citado 2017 set. 19]; 6(8):121-35. Disponível em: https:// saberhumano.emnuvens.com.br/sh/article/ view/137/167
11. Gois PH, Crubellate JM. Relações de poder e o docente - pesquisador frente à estrutura e as estratégias organizacionais na universidade pública. Gestão Org. 2014; 12(1):59-69.

12. Eichler M. Being In-between: reflecting on time, space and career during the tenure application process. New Horizons Adult Educ Hum Res Dev. 2015; 27(2):42-6. doi: http://onlinelibrary.wiley. com/doi/10.1002/nha3.20101/abstract

13. Tavares JP, Beck CLC, Magnago TBS, Zanini RR, Lautert L. Minor psychiatric disorders among nurses university faculties. Rev Latino-Am Enfermagem. 2012; 20(1):175-82. doi: http:// dx.doi.org/10.1590/S0104-11692012000100023

14. Mascarenhas AO, Barbosa ACQ. Produção científica brasileira em gestão de pessoas no período 2000-2010. Rev Adm Empres. 2013; 53(1):35-45. doi: http://dx.doi.org/10.1590/ S0034-75902013000100004

15. Oliveira IR, Camargo ML, Feijó MR, Campos DC, Goulart Júnior E. Empreendedorismo social, pós-modernidade e psicologia: compreendendo conceitos, atuações e contextos. Rev Interinst Psicol. [Internet]. 2016 [citado 2017 set. 19]; 9(2):290-311. Disponível em: http://pepsic. bvsalud.org/pdf/gerais/v9n2/v9n2a10.pdf

16. Aranha EA, Garcia NA. Responsabilidade social corporativa e empreendedorismo: evidências e fragilidades. Desenvolv Quest. 2013; 11(24):26088. doi: http://dx.doi.org/10.21527/22376453.2013.24.260-288

17. Leslie K. Faculty development for academic and career development. In: Steinert Y. Faculty development in the health professions. Toronto: Springer; 2013. p.97-118.

18. Jena S, Sahoo CK. Improving managerial performance: a study on entrepreneurial and leadership competencies. Ind Commer Train. 2014; 46(3):143-9. doi: https://doi.org/10.1108/ICT10-2013-0066 